$\left[\begin{array}{l}\text { Jpn. J. Hosp. Pharm. } \\ \frac{16}{16}(2) \\ 118-124\end{array}\right.$

注射剤からのブプレノルフィン坐㓮の調製とその臨床応用† ${ }^{1}$

中田浩雅 ${ }^{* 2}$, 野田師正 $\dagger^{2}$, 田代克秀 $\dagger^{2}$, 西城一翼 ${ }^{2}$, ,

其田 一 $\dagger^{3}$, 並木昭義 $\dagger^{3}$, 板谷幸一 $\dagger^{2}$

札幌医科大学附属病院薬剂部 $\dagger^{2}$, 同麻醉科 $t^{3}$

\title{
Preparation of Buprenorphine Suppositories from Commercial Injections and Its Clinical Application ${ }^{1}$
}

\author{
HIROMASA NAKATA*2, NORIMASA NODA $\dagger^{2}$, KATSUHIDE TASHIRO ${ }^{2}$, \\ KAZUYOKU SAIJO ${ }^{2}$, HAJIME SONODA $\dagger^{3}$, \\ AKIYOSHI NAMIKI $\dagger^{3}$, KOICHI ITAYA $\dagger^{2}$ \\ Division of Pharmacy $\dagger^{2}$ and Department of Anesthesiology $\dagger^{3}$, \\ Sapporo Medical College Hospital
}

(Received October 16, 1989)

\begin{abstract}
Buprenorphine(BN) is a long-lasting, low-dependent and non-narcotic analgesic, which is effectively employed against various pains, such as cancer, myocardiac and postoperative pain. However, since BN was used only as an injection in Japan, we have planned to adapt it for suppository use for patients who cannot take oral drugs or for home therapy. A method of freeze-drying of the BN injection was chosen on the basis of its simplicity and reproducibility over other methods. With this method, we prepared both a water-soluble, polyethylene glycol based suppository $(200.1 \pm 1.51 \mu \mathrm{g}, \mathrm{n}=5)$ and an oil-soluble, witepsol based suppository (200.8 $\pm 1.70 \mu \mathrm{g}, \mathrm{n}=5$ ). The physical characteristics of each suppository were examined with regard to the pharmaceutical items of weight, BN content, hardness, melting point, liquefaction time and dissolution. In the clinical cross-over test, the rectal administration of both types of suppository showed equally good results.
\end{abstract}

Keywords_-buprenorphine; freeze-drying; suppositories preparation; injections; polyethylene glycol; witepsol; HPLC; cancer pain

モルヒネアルカロイドのテバイン誘導体である ブプレノルフィン (Buprenorphine, 以下 BN) は，身体依存性が低い長時間作用型の非麻薬性鎮 痛剤であり ${ }^{1,2)}$ ，わが国では，術後疼痛，癌性疼 痛, 心筋梗塞痛及び麻酔補助剤として広く使用さ れている

$\dagger$ 日本薬学会第109年会（名古屋，1989年 4 月）で 発表.

$\dagger^{2,3}$ 札幌市中央区南 1 条西16丁目 : Minami 1, Nishi 16, Chuo-ku, Sapporo, 060 Japan
BN 製剤として，諸外国においては注射剂と舌 下錠が市販されているが、わが国では現在のとこ ろ注射剤しか市販されていない.しかしながら， 臨床科から癌性疼痛患者の在宅療法, あるいは緩 徐な疼痛緩和を目的とする意味で, 使用に便利な $\mathrm{BN}$ 坐剂の調製を強く要望された。そこで BN 坐 剂の調製を試みることにしたが，原料とする BN の原末が入手できないため, 市販の注射剂を原料 として利用することを検討した。

注射剤からの坐剤化の試みは，これまでにもい 
くつか報告されているたとえば，BN 注射剂か ら BN 散剤を調製し，さらに坐剤へと製剤化す るといら報告があるが7,8)，操作にやや煩雑な点が あり, 日常業務とするには問題があると思われ た。一方，注射液をそのまま坐剂調製に用いる方 法も報告されているが9)，この場合，1個の坐剂 に保持できる水分は限られるため, BN 含有量が 制限される。

著者らは，BN 注射液を濃縮する際に凍結乾燥 法を用い, 得られた乾燥品から基剤の異なる 2 種 類の坐剂を調製した.今回は, 調製坐剂の製剤学 的検討結果と, その臨床応用の結果について報告 する.

\section{実 験 の 部}

\section{1. 試料及び試薬}

$\mathrm{BN}$ 注射液としては, 塩酸ブプレノルフィンの 含量が $0.216 \mathrm{mg} / \mathrm{ml}$ (BN として $0.2 \mathrm{mg} / \mathrm{ml}$ ) である 1 アンプル $1.5 \mathrm{ml}$ のレペタン®注射液（比 重1.02，大塚製薬，東京）を用いた。内部標準物 質（I.S.）としては塩酸デシプラミン（SIGMA Chemical Co., USA)を用いた.

Polyethylene glycol (PEG) は PEG 400 及 び PEG 4000 (和光純薬, 大阪) を, Witepsol は同一成分のホスュ®E75 及び S55（丸石製薬, 大阪）を用いた。アセトニトリル，メタノール及 びジクロロメタンは HPLC 用（和光純薬，大阪） を, その他の試薬類はすべて市販の試薬特級品を 用いた。

\section{2. $\mathbf{B N}$ 注射液の凍結䡎燥}

注射液 $20.4 \mathrm{~g}$ をビーカーにとり,これを凍結乾 燥機 (EF4 Modulyo, Edwards, USA) 内に 静置し， $-60^{\circ} \mathrm{C}$ で 24 時間放置した．次にこの凍 結品を $0.08 \mathrm{mbar}$ の減圧下で 48 時間放置し, 䄯 華乾燥した。

\section{BN 坐棛の調製}

2. で得られた凍結乾燥品に $2.0 \mathrm{ml}$ の精製水を 加えて得た $\mathrm{BN}$ 溶液 (BN $4 \mathrm{mg}$ 含有) と坐剂用 基剂を混合し， 1 個当りの $\mathrm{BN}$ 含量が $200 \mu \mathrm{g}$ の 坐剂20個を調製した，坐剤用基剤は水溶性基剤の PEG と油脂性基剤の Witepsol を用いた。成型
後の坐剤は冷蔵庫内で保存した。

\section{a) PEG 坐剂}

PEG 400 及び PEG 4000 の比率 1:8 の混合 基剤を加熱溶融し，その $36 \mathrm{~g}$ を $\mathrm{BN}$ 溶液の入っ ているビーカーにとり十分撜找して混合した後， さらに超音波振動を加えた。これを擤拌しながら 約 $47^{\circ} \mathrm{C}$ に冷却した後, 内容量 $1.7 \mathrm{ml}$ の金属性 坐剤コンテナに注入し20個の坐剤を得た.

b) Witepsol 坐剤

ホスコ ${ }^{\circledR S} 55$ を加熱溶融し，その $32 \mathrm{~g}$ BN 溶 液の入っているビーカーにとり十分摜拌して混合 した後，さらに超音波振動を加えた。これを覧拌 しながら約 $35^{\circ} \mathrm{C}$ に冷却した後, 内容量 $1.7 \mathrm{ml}$ の プラスチック性コンテナ（丸石製楽，大阪）に注 入し20個の坐剤を得た.

\section{4. 坐用の製荗学的試験}

\section{a) 重量偏差試験}

坐剂 1 個ごとの重量をセミミク口電子天科 （Sartorius，R180D 型）で測定した.

b ) 硬度測定

$5^{\circ} \mathrm{C}$ の恒温室内で坐剂の中央部を厚さ $1.0 \pm 0.3$ $\mathrm{cm}$ に切断し, 断面部の硬度をモンサント硬度計 （池本理化工業）を用いて測定した。

c) 融点測定

第11改正日本薬局方の一般試験法, 融点測定法 第 2 法に従って測定した.

d) 液化時間

宮崎 ${ }^{10)}$ 及び Iwaoku $5^{11)}$ の方法に従って測 定した。適量の精製水を入れた試験管に坐剂を沈 め, 液温を $37^{\circ} \mathrm{C}$ に保ち, 坐剂が完全に溶融また は融解するまでの時間を測定した。

e ）放出試験

村西ら ${ }^{12)}$ の方法に従い, 坐剂放出試験器（富山 産業, TMS-103 型)を用いて行った. 放出液に は生理食塩液 $300 \mathrm{ml}$ を用い，これを一定の温度 $\left(37 \pm 0.1^{\circ} \mathrm{C}\right)$ に保ち, $100 \mathrm{rpm}$ で㩖拌した。一方, 楽物透析膜としてミリポアフィルター（SSWP 04700, pore size $3 \mu \mathrm{m})$ を用い, 固定した試料 セルには生理食塩液 $3 \mathrm{ml}$ を入れ，その液面が放 出液の液面と一致するようにセルを装置した。 セ ル内に試料を投入後, 直ちに $25 \mathrm{rpm}$ で観找し, 
Table 1. Conditions for HPLC Analysis of BN

\begin{tabular}{l}
\hline Apparatus: Shimadzu Model LC-6A \\
with Rheodyne Model 17125 Injection Valve \\
Detector: Shimadzu Model SPD-6A, Wave Length $280 \mathrm{~nm}$ \\
Sensitivity: $0.01-0.04$ AUFS \\
Column: LiChrosorb Si60, $250 \times 4.0 \mathrm{~mm}$ (i.d.), 10um (Cica-MERCK) \\
Column Temperature: $35^{\circ} \mathrm{C}$ \\
Mobile Phase: $\mathrm{CH}_{3} \mathrm{CN}-\mathrm{CH}_{3} \mathrm{OH}-$ Water (50:5:45) containing $0.2 \% \mathrm{CH}_{3} \mathrm{COONH}_{4}$ \\
Flow Rate: $1.0 \mathrm{ml} / \mathrm{min}$
\end{tabular}

一定時間ごとに放出液 $3 \mathrm{ml}$ を採取した．放出液 の減少分は, 予め $37^{\circ} \mathrm{C}$ に加温した生理食塩液 3 $\mathrm{ml}$ を加えて補正した.

\section{5. 試料からの BN の抽出及び HPLC の測} 定条件

坐剂：坐剂 1 個をジクロロメタン $10 \mathrm{ml}$ に溶解 した後, I.S. 水溶液(塩酸デシプラミン $30 \mu \mathrm{g} / \mathrm{ml}$ ) $1 \mathrm{ml}$ 及び $0.1 \mathrm{~N}$ 塩酸 $3 \mathrm{ml}$ を加え10分間振とう した. 遠心分離後，水相 $4 \mathrm{ml}$ を移し，これにジ クロロメタン $5 \mathrm{ml}$ 及び濃アンモニア水 $0.5 \mathrm{ml}$ を 加え10分間振とらした. 遠心分離後, 有機相 $4 \mathrm{ml}$ をとり減圧乾固した。残渣を移動相 $0.5 \mathrm{ml}$ で溶 解し，その $10 \mu \mathrm{l}$ を HPLC に注入した。

放出液 : 放出液 $2 \mathrm{ml}$ にジクロロメタン $5 \mathrm{ml}$, I.S. 水溶液（塩酸デシプラミン $1 \mu \mathrm{g} / \mathrm{ml}$ ) $0.2 \mathrm{ml}$ 及び濃アンモニア水 $0.2 \mathrm{ml}$ を加光 10 分間遠心分 離後, 有機相を $4 \mathrm{ml}$ とり減圧乾固した. 残渣を 移動相 $0.2 \mathrm{ml}$ で溶解し, その $30 \mu 1$ をPLC に 注入した.

試料中の BN の定量は大谷ら7)の方法を一部改 変して行った. HPLC による測定条件を Table 1 に, 得られたクロマトグラムを Fig. 1 に示す. 対象には妨害ピークは認められず，BN と I.S. の分離も良好である. 坐剤中及び放出液中の $\mathrm{BN}$ 量は, BN と I.S. とのピーク面積 (島津クロマ トパック C-R2A により自動的に算出）の比によ り，検量線を用いて算出した。検量線は, 50〜200 $\mathrm{ng} / \mathrm{ml}$ の濃度範囲でほぼ原点を通る良好な 直 線 関係 $(Y=0.00440 X+0.0157, r=0.997)$ を示し

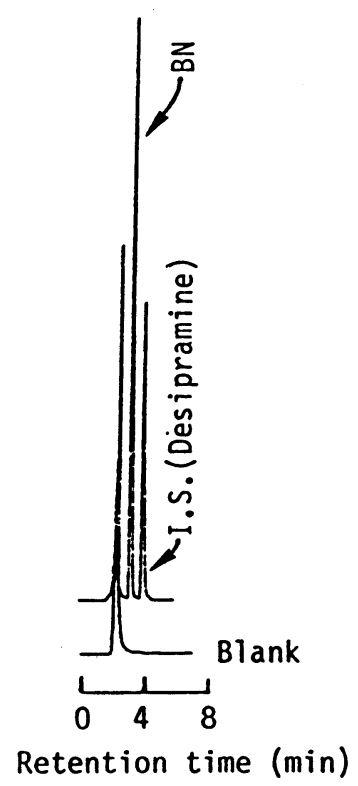

Fig. 1. Typical HPLC Chromatograms

た.また，坐剤からの $\mathrm{BN}$ の添加回収率は $98 \%$ 以上, 操作による変動係数も $4 \%$ 以下と良好であ った.

\section{6. $\mathrm{BN}$ 坐剤の臨床応用}

当院における入院または外来通院患者 9 名につ き, PEG 坐剂及び Witepsol 坐剂を 1 週間の間 隔をおいたクロスオーバー法で，または単独で投 与し, 医師がその除痛効果を除痛スコアにて判定 した。 また， 3 例の患者については血中濃度も測 定した. 


\section{結果と考察}

\section{1. $\mathbf{B N}$ 注射液の凍結䡎燥と䡎燥物の処理}

BN 注射液の濃縮方法として, 加熱濃縮が報告 されているが7)，これは操作が煩雑で，再現性も 得にくいと思われた．著者らは， BN 注射液の濃 縮に凍結乾燥法を用いたが, その結果, 凍結乾燥 前後の $\mathrm{BN}$ 量に変化を与えず， $\mathrm{BN}$ 注射液の水 分をほぼ完全に $(99.8 \pm 0.0981 \%$, 平均 $\pm \mathrm{SD}, \mathrm{n}=$ 5 ) 取り除くことができた。この方法は，多少時 間がかかるが日常業務と平行して進行でき，実質 的操作時間は数分で, 再現性も良い。

乾燥物のほとんどは添加剤として加えられたブ ドウ糖であり, 放置すると吸湿してカラメル状と なるが，少量の精製水を加え，溶液として取り扱
えば問題はない。

\section{2. $\mathbf{B N}$ 坐骫の製剤学的試験}

a) 性状

Table 2 に, PEG 坐剂と Witepsol 坐剂の予 備試験の結果を示す。坐剂の選択基準として硬度 を $3 \mathrm{~kg} / \mathrm{cm}^{2}{ }^{13)}$ 以上と設定した. PEG 坐剂では 処方 $1 \sim 3$ がこの点を満たしている. しかし，処 方 1 と 2 は，硬すぎるためにもろくくずれやすい ので処方 3 を選択した。一方，Witepsol 坐剂で は共に硬度基準は満たしているが，界面活性剂の 添加を必要としないのと調製の容易さといら点で 処方 $\mathrm{I}$ をり上げた．以後は，上記 2 種の坐剤を 用いて本試験に望んだ.

性状試験の結果を Table 3 に示す. PEG 坐剂 及び Witepsol 坐剂はいずれも重量, BN 含量共

Table 2. Formula of PEG and Witepsol Suppositories and It's Hardness

\begin{tabular}{cccc|cccc}
\hline No. & \multicolumn{2}{c|}{ Mixing amount $(\mathrm{g})$} & Hardness $^{*}$ & \multicolumn{2}{c}{ Mixing amount $(\mathrm{g})$} & Hardness $^{*}$ \\
\cline { 2 - 6 } & PEG 400 & PEG 4000 & $\left(\mathrm{Kg} / \mathrm{cm}^{2}\right)$ & No. & Witepsol E-75 & Witepsol $\mathrm{S}-55$ & $\left(\mathrm{Kg} / \mathrm{cm}^{2}\right)$ \\
\hline 1 & 0 & 1.8 & 6.8 & I & 0 & 1.6 & 4.5 \\
2 & 0.1 & 1.7 & 6.0 & II & $0.3^{\star \star}$ & 1.3 & 4.4 \\
3 & 0.2 & 1.6 & 4.5 & & & & \\
4 & 0.3 & 1.5 & 2.8 & & & & \\
5 & 0.4 & 1.4 & n.d. & & & & \\
\hline
\end{tabular}

* Each value represents the mean of five determinations.

** Content of emulsifying agent (Tween 83 ) : $0.1 \mathrm{~g}$

Table 3. Physical Characteristics of BN Suppositories

\begin{tabular}{lccc}
\hline & $\begin{array}{c}\text { Weight } \\
(\mathrm{g})\end{array}$ & $\begin{array}{c}\text { BN content } \\
(\mu \mathrm{g})\end{array}$ & $\begin{array}{c}\text { Hardness } \\
\left(\mathrm{Kg} / \mathrm{cm}^{2}\right)\end{array}$ \\
\hline PEG supp. & $1.92 \pm 0.0222$ & $200.1 \pm 1.51$ & $4.29 \pm 0.190$ \\
Witepsol supp. & $1.64 \pm 0.0165$ & $200.8 \pm 1.70$ & $4.63 \pm 0.886$ \\
\hline & & \\
\hline & $\begin{array}{c}\text { Melting } \\
\text { point }\left({ }^{\circ} \mathrm{C}\right)\end{array}$ & $\begin{array}{c}\text { Liquefaction } \\
\text { time (min) }\end{array}$ \\
\hline PEG supp. & $54.5 \pm 0.250$ & $97.0 \pm 1.58$ \\
Witepsol supp. & $34.3 \pm 0.115$ & $6.50 \pm 0.136$ \\
\hline \multicolumn{3}{c}{ (mean \pm S.D., $\mathrm{n}=5-10)$}
\end{tabular}


にバラッキは少なかった。 また，Witepsol 坐剤 の融点は体温より低く, 液化時間も6.5 分と油脂 性坐剂としては問題のない值であった。

b ) in vitro 放出試験

Fig. 2 は in vitro での放出試験の結果を示し たものである.PEG 坐剤の場合，BN は 1 時間 で50\%が放出し，3時間でほぼ完全に放出した。 一方，Witepsol 坐剤では徐々に放出されてはい るものの 3 時間で約 $20 \%$ と低い值であった.

PEG 坐剂での BN の放出が Witepsol 坐剂に

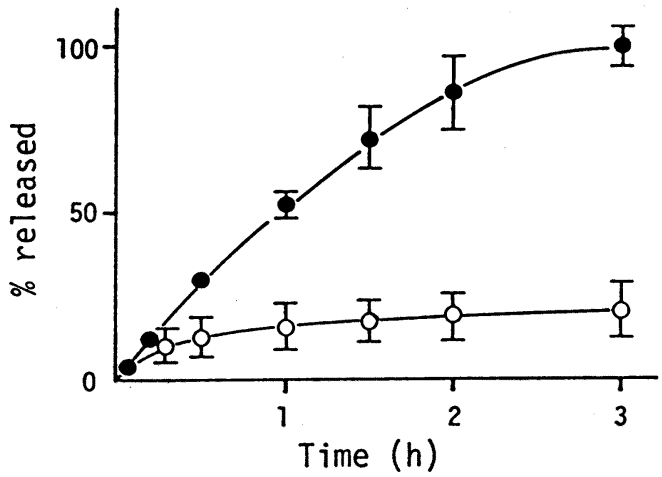

Fig. 2. BN Release from Suppositories

Each point represents mean \pm S. D. $(n=3)$

; PEG supp., $\bigcirc$; Witepsol supp.
比べて速かったのは，基剤が水溶性であるため溶 融後直ちに透析膜を通り放出相（生理食塩液）に 移行したためであり，逆に Witepsol 坐剤では基 剤が溶融しても透析膜上で油状となって残り，そ の中に BN が保持されるため放出相へ出にくく なると考えられる。

\section{3. 坐戍の安定性}

各坐剂を 3 カ月間冷所保存した時の $\mathrm{BN}$ の含 量は, PEG 坐剤 197. $4 \pm 2.6 \mu \mathrm{g} /$ 個 (平均 \pm S. D.,

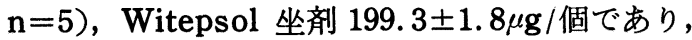
いずれも BN は安定であった。

\section{BN 坐削の臨床使用結果}

対象患者の背景及び使用結果を Table 4 亿示 した。除痛に対する $\mathrm{BN}$ 坐剤の効果は, 著効 3 例，有効 1 例，やや有効 2 例，無効が 3 例 であ った。症例 $1 ， 2$ 及び 7 については PEG 坐剤と Witepsol 坐剂をクロスオーバー法で使用した が，両者に差は認められなかった．副作用は， 3 例で湢気などの消化器症状がみられたが，循環器 や精神・神経症状など重篤なものは認められなか った.

Fig. 3 に症例 2,6 及び 9 の坐剤投与後の血中 濃度を示す． 3 例の患者はいずれも Witepsol 坐

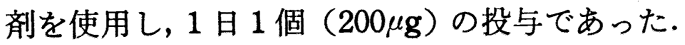

Table 4. Background of the Patients and Clinical Effect

\begin{tabular}{ccccccccc}
\hline $\begin{array}{c}\text { Patient } \\
\text { No. }\end{array}$ & $\begin{array}{c}\text { Age } \\
(\mathrm{yr})\end{array}$ & Sex & $\begin{array}{c}\text { Weight } \\
(\mathrm{kg})\end{array}$ & $\begin{array}{c}\text { Type of } \\
\text { pain }\end{array}$ & $\begin{array}{c}\text { Dose } \\
(\mu \mathrm{g} / \text { day })\end{array}$ & $\begin{array}{c}\text { EEG supp. Witepsol supp. } \\
\text { effect }\end{array}$ \\
\hline 1 & 27 & F & 40 & chronicity & 800 & + & + & Side \\
2 & 49 & M & 88 & chronicity & 200 & +++ & +++ & nausea \\
3 & 59 & F & 38 & chronicity & 200 & +++ & + & + \\
4 & 56 & M & 50 & chronicity & 200 & & + \\
5 & 46 & M & 55 & chronicity & 200 & & nausea \\
6 & 50 & F & 79 & chronicity & 200 & & + \\
7 & 71 & F & 38 & cancer & 600 & +++ &
\end{tabular}

* +++ ; Excellent, ++ ; Good, + ; Poor, - ; None 


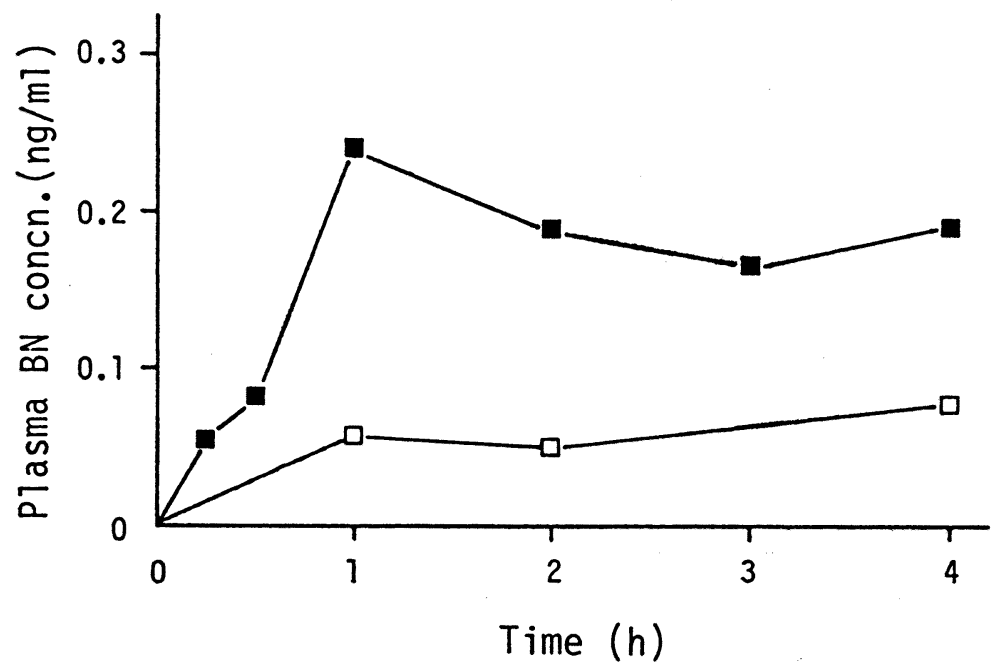

Fig. 3. Time Courses of BN Concentration in Plasma after Administration of BN Suppositories (Witepsol) to Patients

; Patient 9, $\square$; Patient 6, Patient 2 is not detectable

症例 6 は, 投与後 $1 \sim 4$ 時間まで低濃度 $(0.05$ $0.08 \mathrm{ng} / \mathrm{ml}$ ) で推移しているが，除痛は 8 時間持 続した。また，症例 2 は血中濃度が検出限界以下 であったが，除痛は 6 時間持続した。，一方，症例 9 の血中濃度は投与後 1 時間で $0.24 \mathrm{ng} / \mathrm{ml}$ を, 4 時間值でも $0.19 \mathrm{ng} / \mathrm{ml}$ を示したが除痛効果は なかった。

\section{結論}

本法で調製した PEG 坐剤と Witepsol 坐剤 は, in vitro の実験では前者の方が放出性に優れ ていたが，臨床においては，除痛効果に差は認め られなかったことから，共に有用であることが示 された。しかしながら，BN 坐剤はその性質から 一般的に長期連用が考えられるため, 基剤の直腸 粘膜に対する影響を考庶しなければならず，刺激 の多い PEG 坐阂よりは刺激の少ないWitepsol 坐剤の方が適していると思われる.

凍結乾燥法は注射剤から容易に主薬を得ること ができ，時間や手間もかからないため日常の製剤 業務では有用な方法であることが示された．今後 は，含量の異なる坐剤の調製，あるいは舌下製剤 などへの応用も検討したいと考えている。

既辟 本研究にあたり，BN の血中濃度を測定してい
ただいた大塚アッセイ研究所に感謝します。

\section{引用文 献}

1) D. R. Jasinski, J.S. Pevnick and J.D.Griffith, Arch.Gen. Psychiatry, 35, 501-516 (1978).

2) A. Cowan, J.W. Lewis and I. R. Macfarlane, Br.J.Pharmacol., 60, 537-545 (1977).

3）阿部令彦, 吉野篦一, 渡辺洋三, 医学のあゆみ, 121, 300-310 (1982).

4）田口鐵男, 太田 潤, 青木行俊, 医学のあゆみ, $121,1160-1169$ (1982).

5）池田正男, 平盛勝彦, 広沢弘七郎, 医学のあゆ み, 132, 228-247 (1985).

6) 河手真理子, 小川利久, 花岡一雄, 日本臨床麻 醉学会誌, 6, 305-308 (1986).

7) M. Ohtani, F. Shibuya, N. Uehara, H. Kotaki, K. Uchino, K. Nishihara, Y. Saitoh and F. Nakagawa, Yakuzaigaku, 46, 63-68 (1986).

8）大谷道輝，渋谷文則，上原良子，小滝一，内 野克喜, 斎藤侑也, 中川富士雄, 薬郕学, 46 , 229-233 (1986).

9）森川則文, 樋口和子, 武山正治, 塚本豊久, 中 野 節, 喜里山隆之, 寺田 弘, 薬剂学, 47, 115-123 (1987).

10）宮畸順一, 高野正彦, 薬剂学, 15, 218-221 (1956).

11) R. Iwaoku, K. Arimori, M. Nakano and K. Uekama, Chem. Pharm. Bull., 30, 1416-1421 
(1982).

12）村西昌三, 大久保洋子, 瀬崎 亿, 薬剂学, 39,

\section{1-7 (1979).}

13）竹内達雄, 薬剤学, 26, 104-106 (1966).

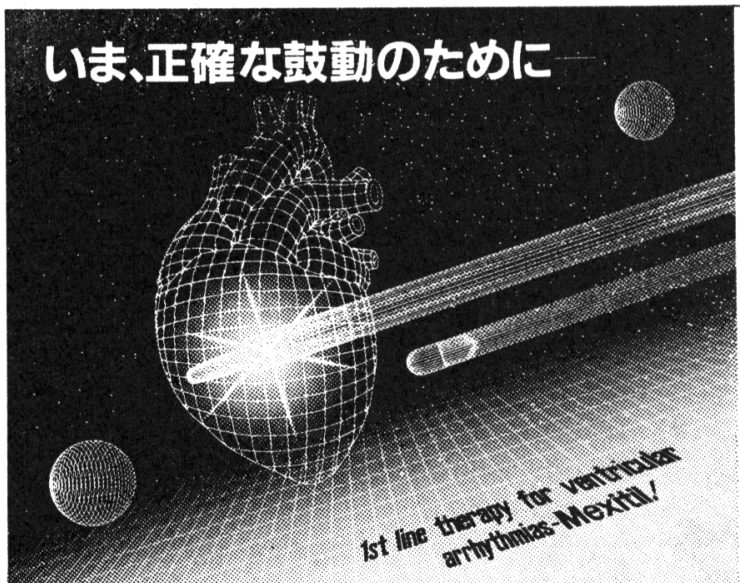

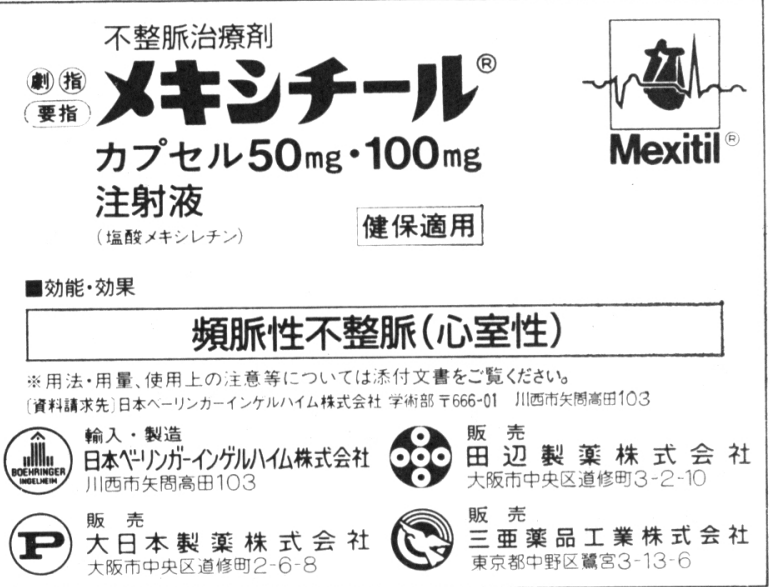

